\title{
AKTUALISASI MAKNA JIHAD DALAM KEHIDUPAN MODERN
}

\author{
Saoki \\ Institut Agama Islam Negeri Sunan Ampel, Jl. A Yani I 17 Surabaya | \\ sauqiamin@gmail.com
}

\begin{abstract}
This article discusses about the essence of the meaning of jihad and its actualization in a modern life. Basically, jihad has two meanings; First, the notion of the propagation of Islam in a polite, tolerant, peaceful way, and away from coercion and violence. Second, the notion of war. Jihad in the first sense to be applied anytime and anywhere, while the second one should only be applied in a very constrained condition because of the definite threat of the enemy. The main purpose of jihad is al-amr bi al-ma'ruf wa al-nahy an al-munkar. Therefore, in today's modern context, jihad could be interpreted in a more macro and holistic sense, so that any forms of al-amr bi al-ma'ruf wa al-nahy an al-munkar like an attempt to increase the level of education of Muslims, an attempt to increase the welfare of the Muslims weather economically, politically, and culturally. All are included in a category of jihad in Islam, and they are more important than a physical jihad with a war, due to the current context, jihad with those meanings are the most needed by Muslims.
\end{abstract}

Keywords: Actualization, Jihad, modern age.

Abstrak: Artikel ini membahas tentang hakekat makna jihad dan aktualisasinya dalam kehidupan modern. Pada dasarnya jihad memiliki dua pengertian; pertama, jihad dengan pengertian dakwah Islam melalui cara yang santun, toleran, damai dan jauh dari unsur pemaksaan dan kekerasan. Kedua, jihad dengan pengertian perang. Jihad dalam pengertian pertama harus diaplikasikan kapan saja dan dimana saja, sedangkan jihad dengan pengertian kedua hanya boleh diaplikasikan dalam kondisi yang sangat terpaksa karena adanya ancaman yang pasti dari musuh. Tujuan utama dari jihad adalah al-amr bi al-ma'ruf wa al-nahy an al-munkar. Untuk itu, jika diletakkan dalam konteks kehidupan modern saat ini, maka jihad bisa dimaknai dalam arti yang lebih makro dan holistik, sehingga segala bentuk al-amr bi al- 
ma'ruf wa al-nahy an al-munkar seperti usaha meningkatkan tingkat pendidikan ummat Islam,usaha meningkatkan kesejahteraan hidup umat Islam,baik secara ekonomi, politik dan budaya. Semuanya masuk dalam kategori jihad dalam Islam, dan lebih utama dibandingkan dengan jihad fisik dengan perang, karena untuk konteks saat ini hal itulah yang paling dibutuhkan oleh umat Islam.

Kata Kunci: Aktualisasi, Jihad, Zaman Modern.

\section{Pendahuluan}

Di penghujung abad ke-20 dan awal abad ke-21 ini, kata jihad sedang menjadi materi perbincangan yang sangat aktual di seluruh penjuru dunia. Hal ini tidak terlepas dari berbagai aksi kekerasan yang terjadi di berbagai belahan dunia. Peristiwa 11 september di Amerika, peristiwa bom Bali, peristiwa bom di Spanyol bahkan aksi kekerasan yang terjadi di negeri-negeri Islam, seperti di Irak, Afganistan dan Palestina. Semua pelaku aksi-aksi kekerasan tersebut selalu mengatasnamakan, atau minimal mengkonotasikannya sebagai perbuatan jihad, sebuah term yang hanya ada di kalangan dunia Islam saja.

Kemudian aksi-aksi kekerasan tersebut oleh orang-orang Barat dijadikan stigma dan dipopulerkan menjadi sebuah perbuatan kejahatan yang dikenal dengan sebutan "teroris". Maka tidak heran, jika kata teroris itu selalu dihubungkan dengan Islam, baik individu, organisasi bahkan dengan institusi yang lebih besar seperti negara, meskipun tidak sedikit aksi-aksi kekerasan di belahan dunia yang dilakukan oleh kalangan non muslim, baik individu maupun institusi.

Teroris (terorism) saat ini telah menjadi isu internasional (international issue) dan telah digiring oleh Barat sebagai sebuah musuh bersama (common enemy) yang harus diwaspadai, dimusuhi dan dihabisi dari muka bumi ini. Teroris yang awalnya murni sebuah kejahatan yang dilakukan oleh oknum-oknum beragama dan bisa jadi tidak ada relevansinya sama sekali dengan agama dalam pengertian sebagai ajaran, kini telah dipropaganda menjadi sesuatu yang bersumber dari agama (Islam), padahal agama itu 
sendiri berbeda dengan keberagamaan (religiosity). Eksesnya terjadilah pergeseran paradigma, yang awalnya "perang melawan teroris" menjadi "perang melawan Islam", bahkan dalam skala yang lebih besar, meminjam istilah Samuel Huntington, perang ini telah bergeser menjadi perang antar peradaban (clash of civilization.$^{1}$

Persepsi di atas yang ada dalam banyak pikiran orang-orang non muslim tidak sepenuhnya bisa disalahkan, karena dalam realitasnya, aksi-aksi kekerasan yang banyak terjadi di negaranegara berpenduduk mayoritas muslim seperti Palestina, Irak, Iran, Mesir, Sudan, Aljazair dan Indonesia sendiri, dalam banyak kasus sering mengatasnamakan jihad.

Secara ideal, Islam adalah agama yang mencintai perdamaian, kasih sayang, toleran, dan menghargai terhadap setiap perbedaan termasuk perbedaan agama dan keyakinan. Bentuk-bentuk pemaksaan, kekerasan dan pertumpahan darah sangat kontradiktif dengan ajaran Islam yang mengagungkan toleransi, kebebasan, rahmat, dan hikmat. Islam adalah agama yang lurus dan melapangkan (hanîf dan samhah). Maka metode penyebaran agama ini lebih banyak menggunakan pendekatan persuasif dan toleran. Al-Qur'an menyebutkan, "Ajaklah ke jalan Tuhanmu, dengan hikmah, nasehat yang baik, atau, debatlah mereka dengan (cara) yang lebih baik" (QS. Al-Nahl [16]: 125). Dalam ayat lain, Islam mengakui kebebasan beragama, "Tidak ada paksaan dalam beragama, (karena) sesungguhnya telah jelas jalan kebenaran dan jalan kesesatan" (QS. Al-Baqarah [2]: 256). Ayat yang lain lebih gamblang, "Barang siapa yang ingin (beriman), maka berimanlah, dan barang siapa yang ingin (kufur), maka kufurlah." Allah menegaskan bahwa tugas Rasulullah hanya sebatas "pemberi peringatan" (mudhakkir) bukan "penguasa" terhadap tingkah laku umatnya. "Maka berilah peringatan, karena kamu hanya sekedar

' Samuel Huntington, Clash of Civilization and The Remaking of World Order, (New York: USA, 1997), 10.

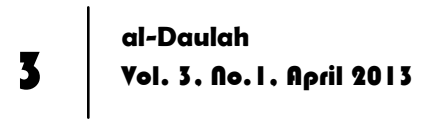


pemberi peringatan, kamu bukanlah orang yang berkuasa atas mereka" (QS Al-Ghâshiyah (88): 22-23).

Tetapi pada sisi lain sulit untuk dibantah bahwa Islam adalah agama yang menganut ajaran jihad yang bisa dipahami dan diartikan dengan arti perang. Dari sini kemudian bisa disalah artikan bahwa Islam mengajarkan dan memerintahkan perang. Maka tidak heran jika kemudian ajaran jihad ini dipahami oleh Barat sebagai "perang suci" (holy war). ${ }^{2}$ Meskipun dalam Islam tidak dikenal istilah perang suci (al-harb al-muqaddasah). Dalam Islam hanya diakui dua bentuk perang, yaitu perang yang disyariatkan (al-harb al-mashrû'ah) dan perang yang tidak disyariatkan (ghayr mashrû'ah).

Adanya perbedaan antara idealisme Islam dengan realitas kondisi ummat Islam terkait dengan ajaran jihad telah menimbulkan banyak kesalahan penafsiran dan pemahaman, baik di kalangan kaum muslim maupun non muslim tentang makna dan cara aplikasi jihad yang sesungguhnya. Untuk itu, tulisan ini akan mengkaji makna ajaran jihad yang sesungguhnya di dalam Islam.

\section{Teks-Teks Suci tentang Jihad}

1. Al-Qur'an surat al-Furqan ayat 52 yang diturunkan di Kota Mekkah:

$$
\text { فَلَا تُطِعِع الْكَافِِِينَ وَجَاهِذْهُم بِهِ ِجهَاداً كَبيراً }
$$

Artinya: "Maka janganlah kamu mengikuti orang-orang kafir, dan berjihadlah terhadap mereka dengan al-Qur'an dengan jihad yang besar"3

2 Bernard Lewis, The Crisis of Islam; Holy War and Unholy War, (New York: Modern Library, 2003), 4. Lihat juga, Karen Armstrong, Holy War: The Crusades And Their Inpact on Today's World. Perang Suci, terj; Hikmat Darmawan, (Jakarta: Serambi Alam Semesta, 2003), 93. Menurut Karen, Perang Suci terjadi merupakan tanggapan terhadap trauma.

3 Departemen Agama Republik Indonesia, al-Qur-an dan Terjemahnya, (Jakarta: PT. Arga Printing, 2008), 488. 
2. Al-Qur'an surat al-Hajj ayat 39:

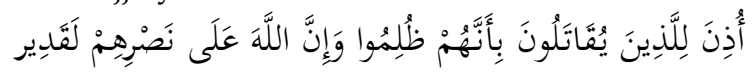

Telah diizinkan (berperang) bagi orang-orang yang diperangi, karena Sesungguhnya mereka telah dianiaya. dan Sesungguhnya Allah, benar-benar Maha Kuasa menolong mereka itu.

3. Al-Qur'an surat at-Taubah ayat 73

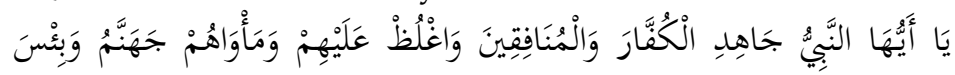
الْمَصِير

Hai Nabi, berjihadlah (melawan) orang-orang kafir dan orangorang munafik itu, dan bersikap keraslah terhadap mereka. tempat mereka ialah Jahannam. dan itu adalah tempat kembali yang seburuk-buruknya.

4. Hadis Nabi:

عن ابن عمر رضي الله عنهما أن رسول الله صلى الله عليه وسلم قال أمرت

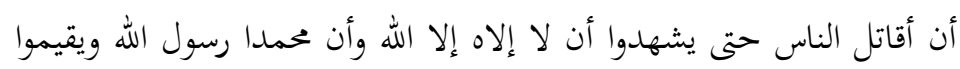

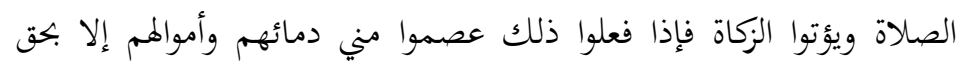
الإسلام وحسابكم على الله تعالى متفق عليه.

"Aku diperintahkan untuk memerangi manusia sampai mereka menyatakan, 'Tiada sesembahan yang haq melainkan Allah.' Jika mereka telah menyatakannya, niscaya darah dan harta mereka aku lindungi kecuali karena haknya." (HR. al-Bukhari dan Muslim).

5. Hadis Nabi:

$$
\text { أفضل الجهاد كلمة حق عند سلطان جائر }
$$

"Paling utamanya jihad adalah berkata benar (haq) di depan penguasa yang zalim (semena-mena)". ${ }^{4}$

\footnotetext{
${ }^{4}$ Hadis ini adalah hadis marfu' dan diriwayatkan oleh Imam Abu Dawud, Imam Tirmidhi dan Ibn Majah dari sahabat Abi Sai'd al-Khudry, dan juga diriwayatkan oleh Imam Ibn Majah, Ahmad ibn
} 
6. Hadis Nabi:

$$
\text { الجهاد أن بتحاهد نفسك وهواك في دات الله تعالي }
$$

"Paling utamanya jihad adalah memerangi hawa nahsumu semata-mata karena Allah". ${ }^{5}$

8. Hadi Nabi;

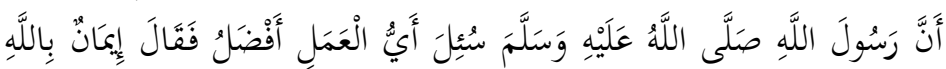

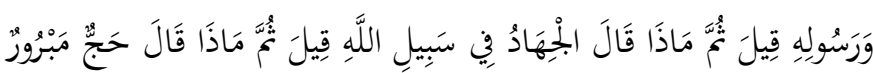

"Rasulullah saw pernah ditanya, "Amalan apakah yang paling utama?" Maka beliau menjawab, "Iman kepada Allah dan RasulNya". Lalu ditanya lagi, "Kemudian apa?" Beliau menjawab, "Jihad di jalan Allah." Lalu beliau ditanya lagi, "Kemudian apa lagi?" Beliau menjawab, "Haji mabrur". (HR. Al-Bukhari no. 1519 dan Muslim no. 83)

9. Hadis Nabi ;

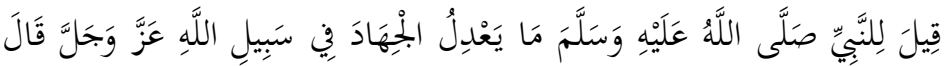

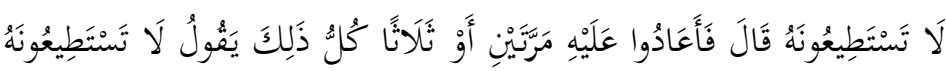

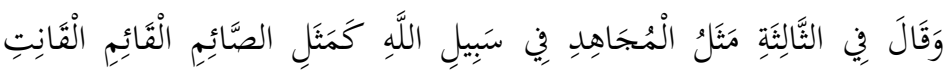

Hanbal, Baihaqi dan T\}abrani dari sahabat Abi Amamah al-Bahili yang berkata, bahwa ketika Nabi melempar jumrah pertama, ada orang menghadap beliau dan bertanya: apa jihad paling utama? Nabi diam tidak menjawab. Ketika Nabi melempar jumrah yang kedua, orang itu bertanya lagi. Nabi diam tidak menjawab. Kemudian ketika Nabi melempar jumrah 'Aqabah, orang itu bertanya lagi. Lalu ketika Nabi sudah di atas punggung unta, belaiau bersabda, dimana orang yang bertanya tadi? Orang itu menjawab, iya saya Nabi. Lalu beliau bersabda, "perkataan yang benar (kalimat haq) di depan penguasa yang zalim". Lihat Abu Isa Ibn Saurah al-Turmuzi, Al-Jami' al-Sahíh, juz 3, (Beirut: Dar al-Kutub al-'llmiyah tt.), 55.

${ }^{5}$ Sa'id Ramadan al-Buti, al-Jihad fi al-Islam Kaifa Nafhamuhu wa Kaifa Numarisuhu, 21. Hadis ini diriwayatkan oleh Imam al-Dailami dari hadis Abi Dharrin, sedangkan Imam Tirmidhi dan Ibn

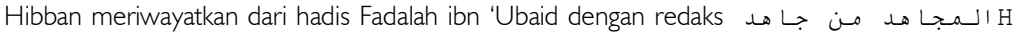
نـــــ Memurut Imam Tirmidhi hadith ini adalah hadis hasan shahih.

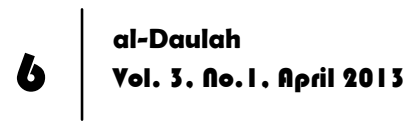




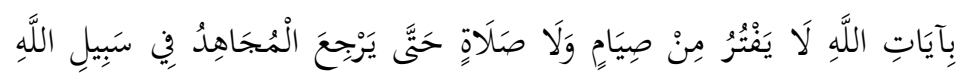
تَعَالَّلى

"Nabi saw pernah ditanya, "Amalan apakah yang (pahalanya) sebanding dengan jihad di jalan Allah Azza wa Jalla?" Beliau menjawab, "Kalian tidak akan sanggup melakukannya." Mereka bertanya lagi sampai dua atau tiga kali. Namun beliau tetap menjawab, "Kalian tidak akan mampu melakukannya." Dan pada kali yang ketiga beliau bersabda, "Perbandingan seorang mujahid fi sabilillah seperti orang yang berpuasa, mendirikan shalat, lagi berdiri lama membaca ayat-ayat Allah. Dan dia tidak berhenti dari puasa dan shalatnya, sehingga seorang mujahid fi sabilillah Ta'ala pulang." (HR. Al-Bukhari no. 2787 dan Muslim no. 1878)

\section{Hakekat Makna Jihad}

Di kalangan para ulama terdapat perselisihan pendapat mengenai makna dan waktu turunnya perintah jihad kepada Nabi dan umat Islam. Kelompok pertama berpandangan bahwa jihad, maknanya adalah perang melawan musuh, dan perintah ini turun setelah Nabi hijrah ke kota Madinah. Pandangan ini tidak sepenuhnya salah, karena memang jihad dalam pengertian perang atau perintah memerangi orang-orang musyrik baru turun setelah Nabi hijrah.

Kelompok kedua berpandangan bahwa mengacu pada masa turunnya ayat tentang jihad, jihad memiliki dua pengertian; pertama, jihad pada masa Nabi hidup, berjuang dan berdakwah Islam di kota Mekkah. Jihad dalam pengertian ini adalah jihad yang diartikan dan dipahami sebagai dakwah amar makruf nahi munkar dengan cara menyampaikan (tabligh) perintah Allah dan rasulNya yang tertuang dalam al-Qur'an dan hadis dengan cara santun dan tanpa paksaan, serta tabah dan teguh dalam menghadapi segala cobaan, siksaan dan rintangan yang diakibatkan oleh dakwah yang dilakukan. Inilah hakikat jihad dalam Islam menurut pandangan kelompok ini, bahkan masih

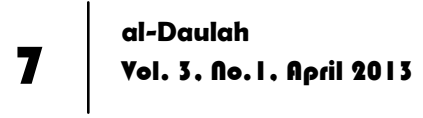


menurut pandangan kelompok kedua ini, jihad dalam bentuk inilah yang telah dilakukan oleh Rasulullah dan para sahabat ketika tinggal di Kota Mekkah. ${ }^{6}$

Dalam analisa kelompok kedua, jihad bukan baru diperintahkan setelah Nabi hijrah ke Madinah. Menurut temuannya, jihad telah diperintahkan dan ada sejak Nabi masih tinggal di Kota Mekkah. Hal ini dibuktikan dengan beberapa firman Allah dan hadis Nabi yang telah mensinyalir bukti-bukti tersebut. Diantaranya: ${ }^{7}$

1. Al-Qur'an surat al-Furqan ayat 52 yang diturunkan di Kota Mekkah:

$$
\text { فَلَا تُطِعِع الْكَافِِِينَ وَجَاهِدْهُم بِهِ ِجهَاداً كَبيراً }
$$

"Maka janganlah kamu mengikuti orang-orang kafir, dan berjihadlah terhadap mereka dengan al-Qur'an dengan jihad yang besar"s

2. Hadis Nabi:

$$
\text { أفضل الجهاد كلمة حق عند سلطان جائر }
$$

"Paling utamanya jihad adalah berkata benar di depan penguasa yang zalim (semena-mena)".

3. Hadis Nabi:

$$
\text { أفضل الجهاد أن بتحاهد نفسك وهواك في دات الله تعالي }
$$

"Paling utamanya jihad adalah memerangi hawa nafsumu sematamata karena Allah".

${ }^{6}$ Sa'id Ramadan al-Buti, Al-Jihad fi al-Islam Kaifa Nafhamuhu wa Kaifa Numarisuhu, (Beirut: Dar alFikr, 1993), 19-22, 63-64.

7 Ibid., 20-2. Menurut Ibn 'Abbas dan sahabat yang lain, pemberian nama jihad yang besar mengandung pengertian bahwa bentuk dan jenis jihad ini adalah sentral dari jenis jihad yang lainnya. Lihat Ibn Kathir, Tafsir Ibn Kathir, (tk: Muassasah Qartabah tt), 32I dan Abi Abdillah Muhammad ibn Ahmad ibn Abi Bakr al-Qurtubi, Tafsir Jami' li Ahkam al-Quran (tk: Muassasah al-Risalah, tt), 85.

${ }^{8}$ DEPAG RI, al-Qur'an dan Terjemahnya (Jakarta: PT. Arga Printing, 2008), 488.

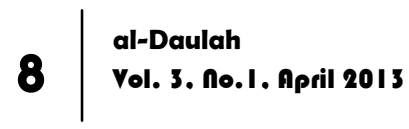


Kedua, jihad setelah Nabi hijrah ke kota Madinah, meskipun masih banyak orang yang mengira bahwa ajaran dan konsep jihad ini baru turun dan disyariatkan setelah Nabi hijrah ke Madinah. Jihad dalam pengertian ini adalah jihad yang dipahami dan diartikan sebagai perang. Menurutnya, konsep dan model jihad yang pertama merupakan dasar, pijakan dan ruh dari model jihad yang lahir sesudahnya termasuk ketika Nabi hijrah ke Madinah. Oleh karena itu menurutnya, jihad itu bisa hadir dalam bentuk dan jenis fisik yang berbeda-beda sesuai dengan situasi dan kondisinya, tetapi harus tetap berpijak pada pondasi dasarnya dan tidak kehilangan ruhnya, yaitu pondasi dan ruh dakwah Islam yang melarang adanya unsur paksaan dan kekerasan dan dilakukan dengan cara-cara persuasif dan dialogis, karena jihad itu merupakan bagian dari dakwah Islam.

Semua jenis jihad yang tidak berkonotasi perang adalah tergolong hakekat dan substansi jihad adalah berasal dari pengertian kata "Jâhad $\hat{u}^{\prime}$ dalam firman Allah, surat al-Nahl ayat 110 yang diturunkan sebelum Nabi hijrah:

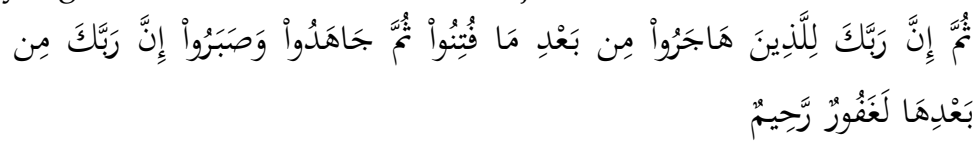

"Kemudian sesungguhnya tuhanmu bagi orang-orang yang hijrah setelah mereka mendapatkan cobaan, lalu berjihad dan bersabar, sesungguhnya tuhanmu sesudahnya adalah Maha Pengampun dan Maha Kasih Sayang. ${ }^{9}$

Dalam pandangan kelompok kedua, lahirnya pengertian jihad dengan makna perang sebenarnya lebih didasari oleh lahirnya kondisi dan situasi baru kehidupan Nabi dan para sahabat di kota Madinah. Secara garis besar kondisi ini dapat diuraikan sebagai berikut:

\footnotetext{
${ }^{9}$ Departemen Agama Republik Indonesia, Al-Qur'an dan Terjemahnya, 364.
}

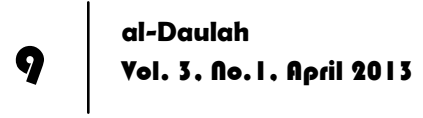


Pertama, lahirnya dan tumbuhnya sebuah masyarakat baru yang saling mengikat diantara anggotanya dalam sebuah sistem negara dan dibawah pimpinan seorang peminpin. Kaum Muhajirin, Ansar dan kaum Yahudi merupakan representasi dari masyarakat ini. Sedangkan konstitusinya adalah Piagam Madinah yang berisi aturan tentang kewajiban dan hak setiap anggota masyarakat ini, dan peminpinnya adalah Rasulullah saw.

Kedua, lahirnya sebuah negara Islam pertama yang berdaulat dengan syarat-syarat yang telah terpenuhi, yaitu adanya anggota masyarakat yang saling mengikat, adanya sistem yang mengatur pola hubungan, hak dan kewajiban setiap anggota masyarakat, adanya seorang peminpin dan adanya wilayah yang menjadi tempat domisili. ${ }^{10}$

Sebagai sebuah negara baru yang berdaulat, maka diperlukan upaya-upaya untuk menjaga eksistensinya serta keberlangsungan kehidupannya sebagai sebuah negara. Hal ini bisa terwujud dengan melakukan langkah-langkah:

Pertama, menjaga perbatasan wilayah negara agar tidak disusupi oleh para musuh yang hendak masuk ke dalam negara atau ke dalam masyarakatnya. Kedua, melakukan langkahlangkah defensif dengan cara memerangi setiap orang yang akan melakukan dan menciptakan situasi instabilitas atau merampas sebagian hak warga negara dan wilayah negara. Ketiga, memerangi setiap orang yang melawan dan membangkang terhadap dakwah Islam yang dilakukan dengan cara dialog, persuasif dan damai. Keempat, memerangi orang-orang Arab yang tetap bersikeras untuk menyembah berhala setelah mereka menerima dakwah dan penjelasan tentang hakikat Islam yang sebenarnya. ${ }^{11}$ Poin yang keempat ini masih menjadi perdebatan di

\footnotetext{
${ }^{10}$ bid., 24.

"Ibid. ada perbedaan pendapat diantara ulama figh tentang poin keempat ini yang akan dijelaskan pada pembahasan selanjutnya. Jenis keempat ini yang dimaksud dengan sabda Nabi dalam hadis riwayat Bukhari dan Muslim dari hadis 'Abdullah ibn 'Umar, " saya diperintahkan untuk memerangi manusia hingga mereka bersaksi bahwa tiada Tuhan selain Allah dan Muhammad adalah utusan Allah, mereka melakukan shalat dan membayar zakat, dan jika mereka telah
} 
kalangan para ulama, karena didalamnya ada unsur paksaan dan kekerasan.

Menurut kelompok ini, jihad dengan perang baru boleh dilakukan jika sudah jelas dan pasti ada ancaman dari pihak musuh setelah diadakan analisa secara mendalam, dan tidak cukup hanya dengan adanya eksistensi musuh dan perkiraan adanya ancaman, dan apabila sudah jelas dan pasti ada ancaman, maka kaum muslimin boleh melakukan penyerangan dan penyerbuan terlebih dahulu agar supaya tidak ada peluang dan kesempatan bagi musuh untuk melakukan serangan pada kaum muslimin. ${ }^{12}$

Pada dasarnya, jihad dalam ajaran Islam bukan merupakan tujuan utama (ultímate goal), tapi hanya merupakan salah satu sarana (wasilah) dakwah Islam. Sebagai bagian dari dakwah Islam, maka jihad dalam implementasinya harus memenuhi prinsipprinsip dakwah yang telah diatur berikut ini:

1. Prinsip Toleran

Dakwah Islam harus dilakukan dengan cara dialog, persuasif dan jauh dari kekerasan serta dalam kerangka memperkenalkan Islam, memberi nasehat dan peringatan seperti yang telah dilakukan oleh Nabi dan para sahabat pada masa awal Islam ketika Nabi hidup di Kota Mekkah. ${ }^{13}$

2. Prinsip Tolong Menolong

Dakwah adalah termasuk dari bagian melaksanakan perintah Allah untuk saling tolong menolong dalam persoalan

melakukan itu semua, maka darah dan harta bendanya telah dilindungi olehku kecuali karena ada hak Islam di dalamnya yang penghitungannya berdasarkan ketentuan Allah". Dilegalkannya peperangan melawan orang orang-orang yang melawan Islam sejak setelah Nabi hijrah, karena pada saat itu dakwah Islam telah dilindungi oleh sebuah negara dan seorang peminpin yang telah memiliki sebuah konstitusi yang melindungi terhadap keberlangsungan dakwah Islam, dimana sebelumnya dakwah Islam itu dilakukan oleh individu-individu yang tidak lindungi oleh sebuah negara, tidak memiliki sebuah wilayah tertentu sebagai tempat domisili dan tidak dipimpin oleh seorang peminpin yang bertanggung jawab secara politik.

12 lbid., $107-108$.

13 lbid., 50-5l. 
kebaikan dan ketakwaan. ${ }^{14}$ Jadi hakikat dari dakwah Islam itu adalah tolong menolong dalam melaksanakan perintah dan kewajiban (taklif) yang datang darinya. Oleh karena itu, sesuai dengan ketentuan tentang taklif, maka seorang muslim memiliki kewajiban berdakwah apabila ia mampu dan atas dasar suka rela bukan karena paksaan atau dalam kondisi terpaksa. Begitu juga dalam melakukan dakwah tidak boleh ada unsur pemaksaan terhadap orang lain, karena dakwah itu hanyalah upaya untuk menyampaikan (tabligh) dan memberi nasehat, tidak lebih dari itu. Untuk memperkuat argumentasinya ini, al-Buti mengutip beberapa firman Allah:

a. Al-Ghashiyah, ayat 21-22:

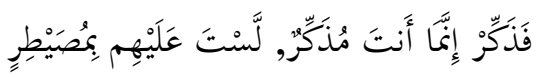

"Maka berilah peringatan, karena sesungguhnya kamu hanyalah orang yang memberi peringatan, kamu bukanlah orang yang berkuasa atas mereka". ${ }^{15}$

b. Al-Shura ayat 48 ,

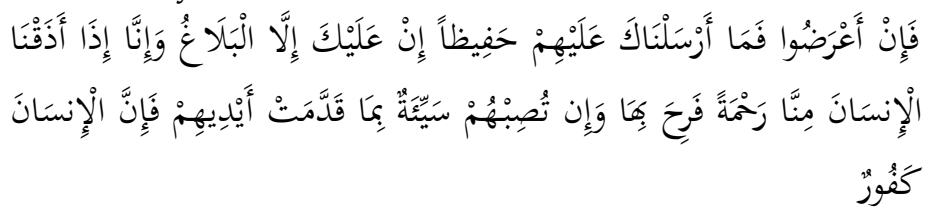

"Jika mereka berpaling maka Kami tidak mengutus kamu sebagai pengawas bagi mereka. Kewajibanmu tidak lain hanyalah menyampaikan (risalah). Sesungguhnya apabila Kami merasakan kepada manusia sesuatu rahmat dari Kami dia bergembira ria karena rahmat itu. Dan jika mereka ditimpa kesusahan disebabkan perbuatan tangan mereka sendiri (niscaya mereka ingkar), karena sesungguhnya manusia itu amat ingkar (kepada nikmat)". ${ }^{16}$

\footnotetext{
${ }^{14}$ Al-Qur-an, 5 (Maidah): 2.

15 Departemen Agama Republik Indonesia, al-Qu-ran dan Terjemahnya, 868.

16 lbid., 674.
} 
c. Al-Ra'd ayat 4017

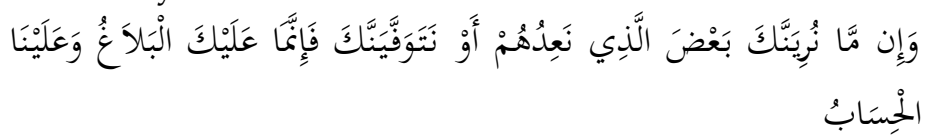

"Dan jika Kami perlihatkan kepadamu sebahagian (siksa) yang Kami ancamkan kepada mereka atau Kami wafatkan kamu (hal itu tidak penting bagimu) karena sesungguhnya tugasmu hanya menyampaikan saja, sedang Kami-lah yang menghisab amalan mereka".

3. Prinsip Ibadah

Hakikat dakwah adalah ibadah kepada Allah, bahkan bisa disebut sebagai aktualisasi tertinggi ibadah kepada Allah, karena seorang da'i dalam melakukan dakwah senantiasa mengarahkan dan berharap seseorang atau sekelompok orang dapat memperoleh hidayah, baik hati maupun pikirannya sehingga akhirnya tumbuh kesadaran bahwa seluruh aktivitas kehidupannya semata-mata hanya untuk memperoleh ridha Allah dan akan menghasilkan pribadi-pribadi yang terdidik dengan benar dan baik, memiliki akhlaq dan etika yang baik pula dalam menjalankan pola interaksi antara sesama. ${ }^{18}$

4. Prinsip Kasih Sayang

Dalam dakwah harus ada rasa cinta dan kasih sayang pada seluruh manusia tanpa membeda-bedakan agama dan keyakinannya. Hal ini baru bisa dilakukan jika seorang da'i sudah bisa mengesampingkan kepentingan-kepentingan pribadi dan duniawinya. Prinsip cinta dan kasih sayang pada seluruh ummat manusia tanpa membeda-bedakan agama dan keyakinannya ini dielaborasi dengan jelas oleh Allah:

a. Dalam al-Qur'an surat al-Anbiya' ayat 107

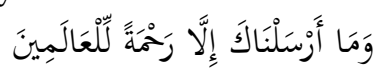

${ }^{17}$ Sa'id Ramadan al-Buti, al--ihad fi al-Islam Kaifa Nafhamuhu wa Kaifa Numarisuhu, 5 I.

${ }^{18}$ Ibid., 64-65. 
"Dan tiadalah Kami mengutus kamu, melainkan untuk (menjadi) rahmat bagi semesta alam". ${ }^{19}$

b. QS. Al-Kahf ayat 58

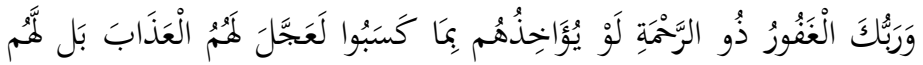

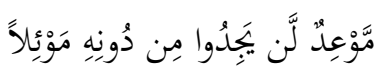

"Dan Tuhanmulah yang Maha Pengampun, lagi mempunyai rahmat. Jika Dia mengazab mereka karena perbuatan mereka, tentu Dia akan menyegerakan azab bagi mereka. Tetapi bagi mereka ada waktu yang tertentu (untuk mendapat azab) yang mereka sekali-kali tidak akan menemukan tempat berlindung dari padanya". ${ }^{20}$

c. QS. Al-A'raf ayat 157:

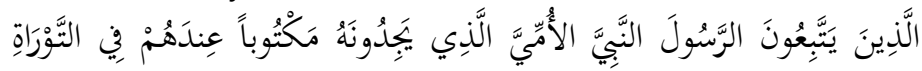

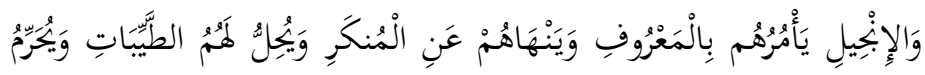

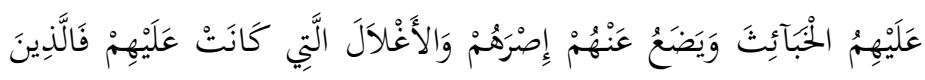

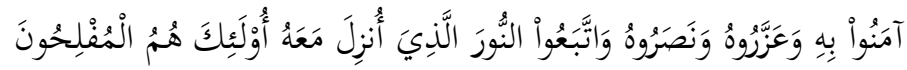
"Yaitu orang-orang yang mengikut Rasul, Nabi yang ummi yang (namanya) mereka dapati tertulis di dalam Taurat dan Injil yang ada di sisi mereka, yang menyuruh mereka mengerjakan yang ma'ruf dan melarang mereka dari mengerjakan yang mungkar dan menghalalkan bagi mereka segala yang baik dan mengharamkan bagi mereka segala yang buruk dan membuang dari mereka beban-beban dan belenggu-belenggu yang ada pada mereka[574]. Maka orang-orang yang beriman kepadanya. memuliakannya, menolongnya dan mengikuti cahaya yang

19 Departeman Agama Republik Indoensia, al-Qur'an dan Terjemahnya, 44I.

20 Sa'id Ramadan al-Buti, al-Jihad fi al-Islam Kaifa Nafhamuhu wa Kaifa Numarisuhu, 394. 
terang yang diturunkan kepadanya (al-Qur'an), mereka itulah orang-orang yang beruntung" 21

Prinsip yang keempat ini juga diperkuat oleh hadis Nabi:
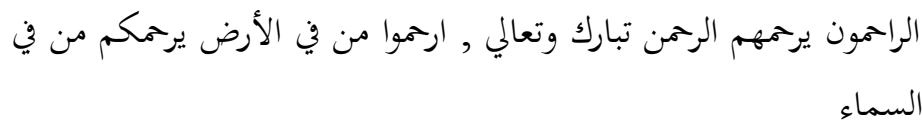

“Orang-orang yang penuh kasih sayang akan disayangi oleh Allah, maka sayangilah seluruh yang ada di bumi, maka seluruh yang ada di langit akan menyangimu pula". ${ }^{22}$

Adapun mengenai keutamaan jihad dibandingkan dengan kedudukan ibadah-ibadah yang lain, secara eksplisit nampak seperti ada keterangan yang tumpang tindih dan saling bertentangan antara yang satu dengan yang lainnya di dalam hadis nabi. Pada suatu waktu Nabi menjelaskan bahwa setelah iman kepada Allah, tidak ada satupun ibadah yang keutamaannya melebihi dari pada jihad fi sabilillah, tapi pada suatu waktu yang lain Nabi menjelaskan bahwa shalat di awal waktu atau berbakti pada kedua orang tua lebih utama dibandingkan jihad.

Menyikapi kondisi ini, para ulama berusaha untuk memberikan jawaban yang terangkum dalam penjelasan berikut ini:

Pertama, perbedaan sabda Nabi tersebut mungkin disebabkab oleh perbedaan penanya, karena Nabi memberikan jawaban sesuai dengan kebutuhan dan kemaslahatan situasi dan kondisi si penanya, atau karena perbedaan waktu. Pada awal Islam, bisa jadi jihad lebih utama dibandingkan dengan ibadah yang lain, karena jihad adalah sarana untuk tegaknya agama Islam, atau kemungkinan yang lain adalah maksud dari kata "paling utama" dalam hadis adalah diantara yang paling

${ }^{21}$ Departemen Agama Republik Indonesia, al-Qur'an dan Terjemahnya, 216.

${ }^{22}$ Sa'id Ramadan al-Buti, al-lihad fi al-Islam Kaifa Nafhamuhu wa Kaifa Numarisuhu ,68. Hadis ini riwayatkan oleh Imam Ahmad, Abu Dawud, Tirmidhi dan Hakim.

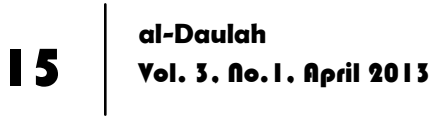


utama. Jadi ada kata "min" (yang berarti diantara) yang dibuang. ${ }^{23}$

Pendapat ini didasarkan kepada sabda Nabi:

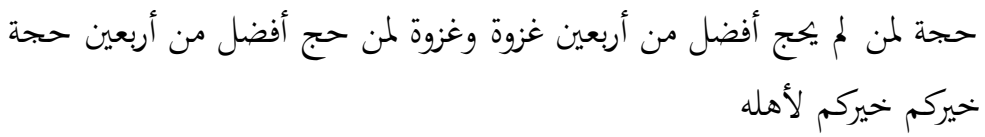

Kedua, pada dasarnya dalam hal ibadah kepada Allah, semua jenis ibadah sama kedudukannya di hadapan Allah. Yang membedakan adalah kondisi masing-masing individu seseorang.bagi orang punya fisik yang kuat, maka yang paling utama baginya adalh jihad, tapi bagi orang yang punya harta yang lebih, maka yang paling utama baginya adalh sedekah. Sedangkan bagi orang yang tidak memiliki keduanya,maka yang paling utama baginya adalah shalat dan zdikir kepada Allah SWT. ${ }^{24}$

Ketiga, dalam Islam segala amal perbuatan terbagi menjadi dua kategori; sarana (wasilah) dan tujuan (gâyah). Sedangkan lebih utamanya shalat, sedekah dan berbakti pada orang tua dari pada jihad, disebabkan shalat, sedekah dan berbakti pada orang tua termasuk kategori tujuan (gâyah) dari ajaran Islam, sedangkan jihad masuk kategori sarana untuk mencapai pada tujuan tersebut (wasâil). Sedangkan secara prinsip (kaedah) al-gâyah ahammu min al-wasâil (tujuan lebih penting dari pada sarana). ${ }^{25}$

\section{Penutup}

Sebuah kesalahan besar jika jihad hanya dimaknai dengan arti perang, meskipun memang tidak bisa dipungkiri bahwa sesuai dengan nash al-Qur'an maupun hadis ada jihad yang artinya

\footnotetext{
${ }^{23}$ Muhammad Khair Haikal, al-Jihad wa al-Qital fi al-Siyasah al-Shar'iyyah, juz 2, (Kairo: Dar Ibn Hazm, I 400 H), 844-846.

${ }^{24}$ Ibid.

${ }^{25} \mathrm{lbid}$, 849
} 
adalah perang, tapi di sisi lain ada juga nash al-Qur'an dan hadis yang menjelaskan bahwa jihad artinya bukan perang tetapi diartikan dan dipahami sebagai dakwah amar makruf nahi munkar dengan cara menyampaikan (tablig) perintah Allah dan rasulNya yang tertuang dalam al-Qur'an dan hadis dengan cara santun dan tanpa paksaan, serta tabah dan teguh dalam menghadapi segala cobaan, siksaan dan rintangan.

Untuk itu, jika diletakkan dalam konteks kehidupan modern saat ini, maka jihad bisa dimaknai dalam arti yang lebih makro dan holistik, sehingga segala bentuk amar makruf dan nahi munkar seperti usaha meningkatkan tingkat pendidikan ummat Islam,usaha meningkatkan kesejahteraan hidup umat Islam,baik secara ekonomi, politik dan budaya. Semuanya masuk dalam kategori jihad dalam Islam, dan lebih utama dibandingkan dengan jihad fisik dengan perang, karena untuk konteks saat ini hal itulah yang paling dibutuhkan oleh umat Islam. ${ }^{26}$

\section{Daftar Pustaka}

Armstrong, Karen. Holy War: The Crusades And Their Inpact on

Today's World. Perang Suci, terj. Hikmat Darmawan. Jakarta:

Serambi Alam Semesta, 2003.

Bukhari (al-), Abi Abdillah Muhammad ibn Ismail. al-Jami' al-Sahih.

Kairo: al-Mat $\{$ ba' ah al-salafiyah, $1400 \mathrm{H}$.

Buti (al-), Muhammad Sa'id Ramadan. al-Jihad fi al-Islam; Kayfa

Nufhimuhu Wa Kayfa Numarisuhu. Damaskus: Dar al-Fikr, 1993.

Departemen Agama RI. al-Qur'an dan Terjemahnya. Jakarta: PT. Arga Printing, 2008.

Haikal, Muhammad Khair. al-Jihad wa al-Qital fi al-Siyasah alShar'iyyah. Juz 2, Kairo: Dar Ibn Hazm,1400 H.

${ }^{26}$ Ibid., 85 I

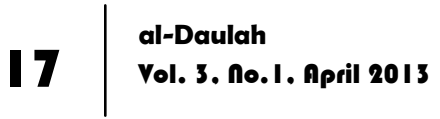


Huntington, Samuel. Clash of Civilization and The Remaking of World Order. New York: USA, 1997.

Ibn Katsir. Tafsir Ibn Katsir. Beirut: Daar Fikr,2005.

Lewis, Bernard. The Crisis of Islam; Holy War and Unholy War. New York: Modern Library, 2003.

Qurtubi (al), Abi Abdillah Muhammad ibn Ahmad ibn Abi Bakr. Tafsir Jami' li Ahkam al-Qur'an. tk: Muassasah al-Risalah, tt.

Turmudhi (al-), Abu Isa Ibn Saurah. Al-Jami' al-Sahí. Beirut: Da>r al-Kutub al-'Ilmiyah tt. 